\title{
Research on paleo-fluid sources and hydrocarbon preservation conditions in marine carbonates in the central Yangtze, China
}

\author{
Wang Guozhi, 2*, Xu Guosheng ${ }^{1}$, Yuan Haifeng ${ }^{1}$, Hu Xiaofeng ${ }^{3}$ and Zou Can ${ }^{4}$ \\ ${ }^{1}$ State Key Laboratory of Oil and Gas Reservoir Geology and Exploitation, Chengdu University of Technology, \\ Chengdu 610059, China \\ ${ }^{2}$ School of Earth Science, Chengdu University of Technology, Chengdu 610059, China \\ ${ }^{3}$ Research Institute of Petroleum Exploration and Development, Jianghan Oilfield Company, SINOPEC, Qianjiang, Hubei \\ 433124, China \\ ${ }^{4}$ College of Foreign Languages \& Cultures, Chengdu University of Technology, Chengdu 610059, China
}

(C) China University of Petroleum (Beijing) and Springer-Verlag Berlin Heidelberg 2011

\begin{abstract}
Sr} /{ }^{86} \mathrm{Sr}, \delta^{18} \mathrm{O}$ and $\delta^{13} \mathrm{C}$ ratios of calcite, dolomite, gypsum filling vugs and fissures in marine carbonates and their host rocks from the Sinian to the middle Triassic, are employed to trace the possible source and migration path of key fluids related to development of hydrocarbon, hydrocarbon preservation condition are then discussed further. Comprehensive research, based on the paleo-fluid, the property of formation water and the deformation intensity etc., indicates that the preservation conditions in the Shizhu synclinorium zone and Fangdoushan anticlinorium zone are the most predominant in the central Yangtze. Three sets of fluid systems in the Shizhu synclinorium zone are identified. Little fluid exchange occurs between the upper- middle fluid system and the lower fluid system, so two independent preservation units have developed. Both the Permian and the Triassic in the upper preservation units and the Dengying Formation of the Sinian and the lower Cambrian in the lower preservation units have good preservation conditions. The preservation condition in the lower association (Z-S) located in the Huaguoping synclinorium zone in the western Hubei and Hunan is better than that in other tectonic units, where the fluids in the lower association migrated vertically across strata when the fluid isolating intervals were destroyed, the regional seals are absent and the conditions for the preservation of hydrocarbon accumulations are totally destroyed. The preservation condition is increasingly more favorable from the western Jiangxi and Hunan to the western Hubei \& eastern Chongqing on the whole.
\end{abstract}

Key words: The central Yangtze, marine carbonate, fluid, ${ }^{87} \mathrm{Sr} r{ }^{86} \mathrm{Sr}$, geochemistry trace, preservation condition

Hydrocarbon exploration of the marine carbonate strata in south China is receiving more and more attention as exploration focus shifts from terrestrial to marine strata (Jin, 2010). The hydrocarbon preservation conditions have become a key point of hydrocarbon exploration in south China (Yang et al, 2002; Fu et al, 2002; Guo et al, 2003). The traditional evaluation on hydrocarbon preservation conditions chiefly revolved around the sealing property of seals and faults as well as the hydrodynamic environment (Surdam, 1997; Chen et al, 2003). Preservation conditions have been significantly degraded and oil-gas reservoirs greatly reconstructed by tectonic activity because oil-gas reservoirs of marine strata

*Corresponding author. email: wangguozhi66@163.com Received July 17, 2010 in south China have undergone several tectonic events. Therefore, traditional evaluation methods are not applicable to hydrocarbon exploration in south China (Ma et al, 2006). Although different integrated parameters, including sealing property of seals and faults, geologic configuration, hydrogeological process and structure, have been employed to evaluate the hydrocarbon preservation condition (Chao and Luo, 1996; Fu et al, 2002; Guo et al, 2003; Chen et al, 2004; Ai et al, 2006; Jin et al, 2006; Lou et al, 2006; Hu et al, 2007), and different hydrocarbon preservation units or types have been classified in the marine carbonates in the central Yangtze (Pan and Yang, 1992; Yang et al, 2002; He et al, 2004; Ma et al, 2004; Wo and Wang, 2009), effective methods are still insufficient for evaluating hydrocarbon preservation. There is a new method for hydrocarbon preservation evaluation from the perspective of paleo-fluid geochemistry (Wang and 
Liu, 2009). On the basis of this new evaluation method, in this paper we report use of an isotope geochemical approach to detect the possible sources and migration paths of key paleo-fluids, and then to make a preliminary evaluation of the preservation condition of the reservoirs in the marine carbonate areas in the central Yangtze according to the fluid source in the strata overlying the seal.

\section{Research clue and approach}

In superimposed basins, multi-phase tectonic activities may result in the release of multiphase fluids and development of multiphase mineral infilling in vugs and fissures. The dynamic evaluation of preservation conditions exploiting paleo-fluid means that each fluid, especially those key fluids were traced geologically and geochemically to determine whether the fluids in strata overlying seals were from a paleoreservoir/gas pool or just meteoric water filtering downwards. In this way, the sealing properties at different stages could be estimated.

\subsection{Building of fluid activities sequence}

The fluid infilling sequence was determined from the relative time sequence relationship of the mineral infillings in reservoir vugs and intercept relationship of fissures. The fluid activities sequence can be reconstructed and key fluids can be determined according to the relative time sequence of oil and gas generation: pre-oil window, oil window, pre-gas window, gas window and post-gas window (Heydari, 2000; Wang and Liu, 2009). The Key fluids are those infilling after the oil window but before the gas window and those after the gas window. The source of key fluid was traced from geochemistry to evaluate the preservation condition after oil and gas were generated. The bitumen from oil thermal cracking and oil/gas inclusions could be used to confirm the key fluid infilling sequence comprehensively. Salt water inclusions after the oil window and before the gas window contain plenty of liquid oil phases. Most fluid infilling during the post gas window developed after thermal cracking bitumen and gas phase methane inclusions were usually either abundant or absent. Methane formed during the gas window could also dissolve in water to exist in the form of liquid under the super-pressure (Wang et al, 2003).

\subsection{Geochemical trace of fluid source}

Two kinds of fluids can be classified according to the difference of fluid source: authigenic and allogenic fluids. Authigenic fluids refer to those from the adjacent host rocks or from other parts of host strata themselves. Allogenic fluids were those from elsewhere, including magmatic fluid, postmagmatic hydrothermal fluid and meteoric water. The source of authigenic or allogenic fluids can be traced by examination of strontium isotopes and carbon \& oxygen isotope ratios (Wang and Liu, 2009).

The deposition of $\mathrm{Sr}$ in the calcite lattice would not result in isotope fractionation (Faure, 1977). The ${ }^{87} \mathrm{Sr} /{ }^{86} \mathrm{Sr}$ of calcite was almost equal to that of initial fluid when mineral crystallized if there was no violent alteration in later periods (Reinhardt et al, 1998). Thus, the ${ }^{87} \mathrm{Sr} /{ }^{86} \mathrm{Sr}$ of fluid could be determined by direct measurement of the ${ }^{87} \mathrm{Sr} /{ }^{86} \mathrm{Sr}$ of carbonate minerals or gypsum infilling in vugs and fissures. Research indicated that residence time of strontium in seawater was considerably longer than seawater blending time. Therefore, the isotopic composition of marine strontium in any age was uniform globally which accordingly made the isotopic composition of strontium in seawater geologically function of time (McArthur et al, 1994; Huang et al, 2004). When marine cogenetic minerals (such as abiogenetic or biogenetic carbonate components of sediments) formed they included strontium from seawater, but isotopic fractionation could be ignored (Banner and Kaufman, 1994). The carbonates depositing from seawater retained the ${ }^{87} \mathrm{Sr} /{ }^{86} \mathrm{Sr}$ of seawater when they formed (McArthur et a1, 1994; Huang et al, 2004). The strontium isotope curve of seawater globally over time has been determined based on the endeavor of geologists (McArthur et al, 1994). A definite value or a stable variation range of strontium isotope ratios of seawater in a certain age was different from that of seawater in other ages. Therefore, after the ${ }^{87} \mathrm{Sr} /{ }^{86} \mathrm{Sr}$ of infillings in vugs or fissures was measured and compared to that of seawater in different ages, it could be determined that the fluid was from redissolution of carbonates from identifiable strata of the same age or of different ages, or belonged to other fluid source.

Unlike the strontium isotope ratio, the carbon and oxygen isotopes of calcite crystallizing from a hydrothermal system was not only affected by the original isotope composition of the hydrothermal fluid but also by the temperature when mineral crystallized and the types of dissolved carbon in hydrothermal fluid (Zheng, 2001). In contrast, strontium is not affected by isotopic fractionation and the $\mathrm{Sr}$ isotope ratio of an original fluid would vary distinctively even if just a little foreign fluid was mixed with it (Wang and Liu, 2009). Thus, it is far more effective to trace the source of fluid by employing strontium isotopes than carbon and oxygen isotopes. Pairing analysis of strontium and carbon \& oxygen isotope ratios of infillings in vugs and fissures and host strata is required to recognize authigenic and allogenic fluid. Authigenic fluid is characterized by similar ${ }^{87} \mathrm{Sr} /{ }^{86} \mathrm{Sr}$ between infillings and contemporary seawater of host rocks and obvious $\delta^{13} \mathrm{C}$ and $\delta^{18} \mathrm{O}$ difference or similar $\delta^{13} \mathrm{C}$ and $\delta^{18} \mathrm{O}$ between infillings and host rocks, while allogenic fluid is characterized by an obvious ${ }^{87} \mathrm{Sr} /{ }^{86} \mathrm{Sr}$ difference between infillings and contemporary seawater of host rocks (Wang and Liu, 2009).

\section{Division of tectonic units in the central Yangtze}

The central Yangtze is located in the center of the Yangtze Plate with the south China fold belt in the south and the Qinling-Dabie fold belt in the north (Fig. 1a). Marine and continental congruent basins developed in its hinterland. The marine sediments exploration area in the central Yangtze can be divided into three blocks as follows: one in west Hubei and east Chongqing, one in west Hunan and Hubei and the last in the Jianghan Plain. Every block could be divided further into several secondary tectonic units (Ma et al, 2004) (Fig.1b). Among them, the block in west Hubei and east Chongqing 
consists of many tectonic units including the Fangdoushan anticlinorium zone, the Shizhu synclinorium zone, the Qiyueshan anticlinorium zone and the Lichuan synclinorium zone. The block in west Hunan and Hubei consists of many tectonic units including the central anticlinorium zone, the Huaguoping synclinorium zone, the Yidu-Hefeng anticlinorium zone, the Sangzhi-Shimen synclinorium zone, the Zigui synclinorium zone, the Huangling anticline zone and the Shennongjia anticlinorium zone. The Jianghan Plain includes the Dangyang synclinorium zone, the LexiangguanQianjiang anticlinorium zone, the Chenhu-Tuditang synclinorium zone, the Chongyang-Tongshan thrust faulted anticline belt zone and the Ba-Hong thrust faulted anticline belt zone.

This paper mainly focuses on the paleo-fluid sources and hydrocarbon preservation conditions in west Hubei and east Chongqing as well as west Hunan and Hubei. The correlational research findings from the Jianghan Plain will be reported in a separate paper. The samples used for research and their tectonic location are showed in Fig.1. The analytical results of ${ }^{87} \mathrm{Sr} /{ }^{86} \mathrm{Sr}, \delta^{13} \mathrm{C}$ and $\delta^{18} \mathrm{O}$ of all samples were listed in Table 1.

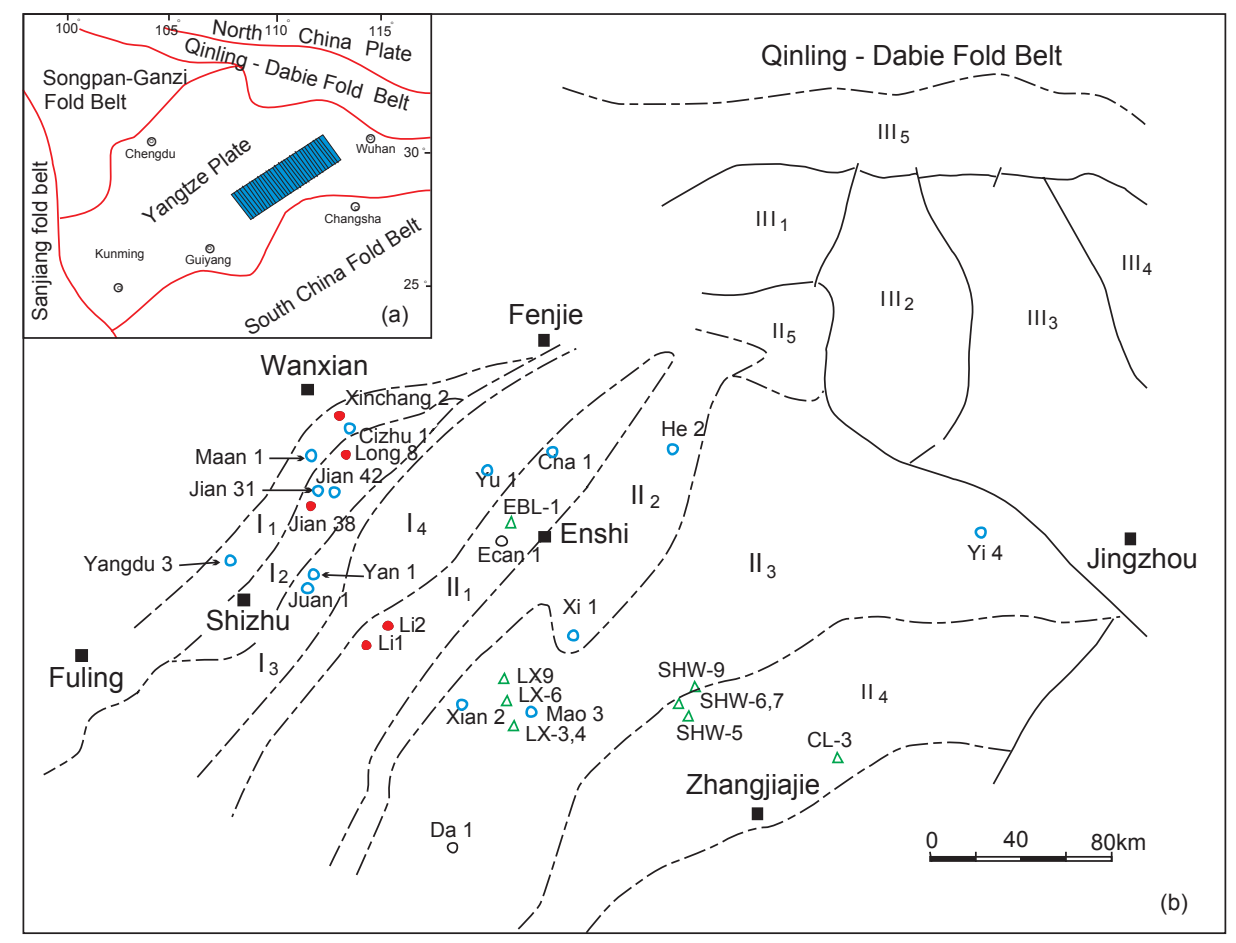

Fig. 1 Division of tectonic unit in the central Yangtze area (modified after Ma et al, 2004)

(a) Tectonic location, the blue square with oblique line: research area; red line: faults. (b) Tectonic units. Red circle: sample drilling site; blue hollow circle: drilling with hydrogeochemistry data. Green triangle: location of outcrop sample. $I_{1}$ : Fangdoushan anticlinorium zone; ${ }_{2}$ : Shizhu synclinorium zone; $\mathrm{I}_{3}$ : Qiyueshan anticlinorium zone; $\mathrm{I}_{4}$ : Lichuan synclinorium zone. $\|_{1}$ : Central anticlinorium zone; $\|_{2}$ : Huaguoping synclinorium zone; $\|_{3}$ : Yidu-Hefeng anticlinorium zone; $\|_{4}$ : Sangzhi-Shimen synclinorium zone, $\|_{5}$ : Zigui synclinorium zone. III ${ }_{1}$ : Shennongjia anticlinorium zone; III ${ }_{2}$ : Huangling anticline zone; III ${ }_{3}$ : Dangyang synclinorium zone, $\mathrm{II}_{4}$ :LexiangguanQianjiang anticlinorium zone; $\mathrm{III}_{5}$ : Ba-Hong thrust faulted anticline zone.

\section{Paleo-fluid and its preservation conditions in west Hubei and east Chongqing}

\subsection{Fangdoushan anticlinorium zone}

Xinchang 2 well (location see Fig.1b) located on the tectonic belt of the NW wing of the Fangdoushan anticlinorium zone, was chosen as an example. The sample taken from the Xinchang 2 well was from the $2^{\text {nd }}$ Member in the Changxing Formation of the upper Permian $\left(\mathrm{P}_{2} \mathrm{ch}^{2}\right)$. The lithology of host rocks was grey micrite in general with better development of vugs and fissures. Vugs and fissures were often infilled with crystalline gypsum and slightly deep grey fine crystalline to medium-crystalline calcite. By observing the fluid inclusions in calcite, it was found that there are gasliquid phase saltwater inclusions and plentiful organic inclu- sions. All inclusions were quite regular in shape and $3-17 \mu \mathrm{m}$ across. Raman spectral analysis showed that the organic phases mainly consisted of liquid methane. The existence of abundant methane inclusions showed that the infilling of fluid occurred during gas window or post-gas window.

Research showed that the obviously higher ${ }^{87} \mathrm{Sr} /{ }^{86} \mathrm{Sr}$ of gypsum (0.7100) (Table 1) infilling vugs in the upper Permian than that of contemporary normal seawater (between 0.7067 0.7076, Shi et al, 2002) showed that the fluid forming gypsum was allogenic, richer in strontium 87 from outside the upper Permian. The similar ${ }^{87} \mathrm{Sr} /{ }^{86} \mathrm{Sr}$ of seawater of the early and middle Cambrian (between 0.7087-0.7100) (McArthur et a1, 1994; Denison et al, 1998) to that of the gypsum indicated that the fluid forming the gypsum could have come from the lower and middle Cambrian sediments which contain 
Table 1 Results of ${ }^{87} \mathrm{Sr} /{ }^{86} \mathrm{Sr}, \delta^{13} \mathrm{C}$ and $\delta^{18} \mathrm{O}$ for paired samples from different tectonic unit

\begin{tabular}{|c|c|c|c|c|c|c|c|c|c|c|c|}
\hline \multirow{2}{*}{$\begin{array}{l}\text { Well No. or } \\
\text { profile name }\end{array}$} & \multirow{2}{*}{$\begin{array}{c}\text { Sample } \\
\text { No. }\end{array}$} & \multirow{2}{*}{ Lithology } & \multirow{2}{*}{$\begin{array}{l}\text { Well depth } \\
\text { m }\end{array}$} & \multirow{2}{*}{ Interval } & \multirow{2}{*}{$\begin{array}{c}{ }^{87} \mathrm{Sr} /{ }^{86} \mathrm{Sr} \\
\% о\end{array}$} & \multirow{2}{*}{$\begin{array}{c}\delta^{13} \mathrm{C}, \% \\
\mathrm{PDB}\end{array}$} & \multirow{2}{*}{$\begin{array}{c}\delta^{18} \mathrm{O}, \% 0 \\
\mathrm{PDB}\end{array}$} & \multicolumn{3}{|c|}{$\Delta_{(\mathrm{V}-\mathrm{C})}, \% 0$} & \multirow{2}{*}{ Tectonic unit } \\
\hline & & & & & & & & $\Delta^{87} \mathrm{Sr} /{ }^{86} \mathrm{Sr}$ & $\Delta \delta^{13} \mathrm{C}$ & $\Delta \delta^{18} \mathrm{O}$ & \\
\hline \multirow{5}{*}{ Xinchang 2 well } & $\mathrm{Xc2}-15 \mathrm{~V}$ & gypsum & 3340.50 & $\mathrm{P}_{2} \mathrm{ch}^{2}$ & 0.7100 & - & - & - & - & - & \multirow{5}{*}{$\begin{array}{l}\text { Fangdoushan } \\
\text { anticlinorium zone }\end{array}$} \\
\hline & $\mathrm{Xc2}-17 \mathrm{~V}$ & calcite & \multirow{2}{*}{3370.00} & \multirow{2}{*}{$\mathrm{P}_{2} \mathrm{ch}^{2}$} & 0.7075 & -5.647 & 4.708 & \multirow{2}{*}{0.076} & \multirow{2}{*}{-1.217} & \multirow{2}{*}{0.0004} & \\
\hline & $\mathrm{Xc2}-17 \mathrm{C}$ & micrite & & & 0.7071 & -4.430 & 4.632 & & & & \\
\hline & $\mathrm{Xc2}-21 \mathrm{~V}$ & patch calcite & \multirow{2}{*}{3375.64} & \multirow{2}{*}{$\mathrm{P}_{2} \mathrm{ch}^{2}$} & 0.7074 & -6.980 & 4.946 & \multirow{2}{*}{0.204} & \multirow{2}{*}{-2.79} & \multirow{2}{*}{0.0004} & \\
\hline & $\mathrm{Xc} 2-21 \mathrm{C}$ & micrite & & & 0.7070 & -4.190 & 4.742 & & & & \\
\hline \multirow{4}{*}{ Jian 38 well } & $\mathrm{J} 38-6 \mathrm{~V}$ & calcite & \multirow{2}{*}{3151.42} & $T f^{3}$ & 0.7075 & -7.113 & 4.070 & 0.127 & 2008 & & \\
\hline & $\mathrm{J} 38-6 \mathrm{C}$ & micrite & & $11^{1}$ & - & -5.105 & 4.497 & -0.721 & -2.000 & 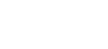 & \\
\hline & J38-9V & calcite & 315320 & $T f^{3}$ & 0.7075 & -6.611 & 3.748 & ก 208 & 021 & 00001 & \\
\hline & $\mathrm{J} 38-9 \mathrm{C}$ & calcarenite & (2) & $1_{11}^{1}$ & 0.7076 & -6.401 & 3.956 & -0.200 & -0.21 & -0.0001 & \\
\hline & Bao10V & calcite & 431467 & $\mathrm{P}_{2} \mathrm{Ch}^{2}$ & 0.7071 & -6.263 & 3.747 & -0.339 & -0182 & $\ldots$ & Shizhu \\
\hline & Bao10C & micrite & (20) & & - & -6.081 & 4.086 & & - 0.40 & & anticlinorium zone \\
\hline Long 8 well & Bao19V & calcite & 155784 & $\mathrm{D} \mathrm{m}^{3}+\mathrm{C}^{2}$ & 0.7071 & -5.908 & 4.111 & 0238 & 0726 & & \\
\hline & Bao19C & micrite & דים & $I_{1 \mathrm{~m}}$ & - & -5.182 & 3.873 & 0.250 & -0.120 & & \\
\hline & Bao22V & calcite & 178448 & $\mathrm{D} \mathrm{m}^{1}$ & 0.7071 & -5.146 & 4.108 & 0201 & 0410 & & \\
\hline & Bao22C & micrite & & $x_{1 \mathrm{~m}}$ & - & -4.727 & 3.817 & 0.271 & -0.71 & & \\
\hline & Li1-1V & calcite & & & 0.7092 & -1.681 & -13.269 & & & & \\
\hline & Li1-1C & dolomicrite & 270.0 & $-3^{\circ}$ & 0.7093 & -0.101 & -9.739 & -0.0001 & -1.00 & 0.00 & \\
\hline Li 1 well & Li1-3V & calcite & 4883 & $\epsilon, s$ & 0.7092 & -1.770 & -13.453 & -0.0002 & -1669 & -3.804 & Central \\
\hline & Li1-3C & dolomicrite & & & 0.7094 & -0.101 & -9.649 & & & & anticlinorium zone \\
\hline & Li1-4V & calcite & 2878.0 & $\epsilon_{1} \mathrm{sp}$ & 0.7086 & 3.428 & -9.105 & - & - & - & \\
\hline Poinubo Drofil & EBL-1V & calcite & & $6 b_{7}$ & 0.7116 & - & - & 00032 & & & \\
\hline 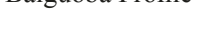 & EBL-1C & micrite & & - je & 0.7083 & - & - & 0.000 & & & \\
\hline & Li2-1V & Dolomite & & & 0.7096 & 3.474 & -7.455 & & & & \\
\hline & Li2-1C & dolomicrite & $2+7+1.72$ & $-30 \mathrm{P}$ & 0.7096 & -0.698 & -9.736 & 0.0000 & 0.120 & 1.000 & \\
\hline Li 2 well & Li2-4V & calcite & 3396.70 & $7 \mathrm{dv}^{3}$ & 0.7097 & - & - & 00003 & - & - & anticlinorium \\
\hline 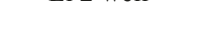 & Li2-4C & dolomicrite & 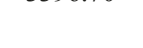 & & 0.7094 & - & - & (1) & & & zone \\
\hline & Li2-5V & calcite & & & 0.7097 & -7.278 & -14.835 & & & & \\
\hline & Li2-5C & dolomicrite & 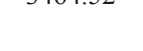 & $2_{2}+y_{j}$ & 0.7094 & -4.307 & -8.403 & 0.0000 & 2.071 & -0.752 & \\
\hline & LX-6V & calcite & & & 0.7116 & - & - & 00004 & - & - & \\
\hline & LX-6C & calcisiltite & & 3 & 0.7092 & - & - & & - & - & \\
\hline & LX-3V & calcite & & & 0.7116 & - & - & 0021 & - & - & \\
\hline Laifeng- & LX-3C & micrite & & & 0.7095 & - & - & 0.0021 & - & - & $\begin{array}{l}\text { Yidu-Hefeng } \\
\text { anticlinorium }\end{array}$ \\
\hline Profile & LX-4V & calcite & & $\mathrm{O}_{\alpha}$ & 0.7116 & - & - & 00019 & - & - & zone \\
\hline & LX-4C & micrite & & & 0.7097 & - & - & & - & - & \\
\hline & LX-9V & dolomite & & & 0.7114 & - & - & & - & - & \\
\hline & LX-9C & $\begin{array}{l}\text { dolomitic } \\
\text { limestone }\end{array}$ & - & $\epsilon_{1}$ & 0.7086 & - & - & 0.0028 & - & - & \\
\hline
\end{tabular}




\begin{tabular}{|c|c|c|c|c|c|c|c|c|c|c|c|}
\hline \multirow{2}{*}{$\begin{array}{l}\text { Well No. or } \\
\text { Profile Name }\end{array}$} & \multirow{2}{*}{$\begin{array}{l}\text { Sample } \\
\text { No. }\end{array}$} & \multirow{2}{*}{ Lithology } & \multirow{2}{*}{$\begin{array}{l}\text { Well depth } \\
\text { m }\end{array}$} & \multirow{2}{*}{ Interval } & \multirow{2}{*}{$\begin{array}{c}{ }^{87} \mathrm{Sr} /{ }^{86} \mathrm{Sr} \\
\% 0\end{array}$} & \multirow{2}{*}{$\begin{array}{c}\delta^{13} \mathrm{C}, \% 0 \\
\mathrm{PDB}\end{array}$} & \multirow{2}{*}{$\begin{array}{c}\delta^{18} \mathrm{O}, \% \text { o } \\
\text { PDB }\end{array}$} & \multicolumn{3}{|c|}{$\Delta_{(\mathrm{V}-\mathrm{C})}, \% 0$} & \multirow{2}{*}{ Tectonic unit } \\
\hline & & & & & & & & $\Delta^{87} \mathrm{Sr} /{ }^{86} \mathrm{Sr}$ & $\Delta \delta^{13} \mathrm{C}$ & $\Delta \delta^{18} \mathrm{O}$ & \\
\hline \multirow{2}{*}{$\begin{array}{l}\text { Cili-Nanshanping } \\
\text { Profile }\end{array}$} & CL-3V & calcite & \multirow{2}{*}{-} & \multirow{2}{*}{$\mathrm{Z}_{2} \mathrm{dy}$} & 0.7114 & - & - & \multirow{2}{*}{0.0011} & - & - & \multirow{10}{*}{$\begin{array}{c}\text { Sangzhi- } \\
\text { Shimen } \\
\text { synclinorium } \\
\text { zone }\end{array}$} \\
\hline & CL-3C & dolomicrite & & & 0.7103 & - & - & & - & - & \\
\hline \multirow{8}{*}{$\begin{array}{l}\text { Sangzhi- } \\
\text { Hongjiaguan- } \\
\text { Wudaoshui } \\
\text { Profile }\end{array}$} & SHW-5V & calcite & \multirow{2}{*}{-} & \multirow{2}{*}{$\mathrm{O}_{1} \mathrm{~h}$} & 0.7115 & - & - & \multirow{2}{*}{0.0019} & - & - & \\
\hline & SHW-5C & calcarenite & & & 0.7096 & - & - & & - & - & \\
\hline & SHW-6V & calcite & \multirow[b]{2}{*}{-} & \multirow[b]{2}{*}{$\epsilon_{3} \mathrm{~s}$} & 0.7115 & - & - & \multirow[b]{2}{*}{0.0019} & - & - & \\
\hline & SHW-6C & $\begin{array}{c}\text { micrite } \\
\text { dolomicrite }\end{array}$ & & & 0.7096 & - & - & & - & - & \\
\hline & SHW-7V & calcite & \multirow[b]{2}{*}{-} & \multirow[b]{2}{*}{$\epsilon_{3} \mathrm{~s}$} & 0.7114 & - & - & \multirow[b]{2}{*}{0.0019} & - & - & \\
\hline & SHW-7C & $\begin{array}{c}\text { calcareous } \\
\text { dolomite }\end{array}$ & & & 0.7095 & - & - & & - & - & \\
\hline & SHW-9V & dolomite & \multirow[b]{2}{*}{-} & \multirow[b]{2}{*}{$\epsilon_{3} \mathrm{~s}$} & 0.7116 & - & - & \multirow[b]{2}{*}{0.0017} & - & - & \\
\hline & SHW-9C & $\begin{array}{l}\text { calcareous do- } \\
\text { lomite }\end{array}$ & & & 0.7099 & - & - & & - & - & \\
\hline
\end{tabular}

Notes: C stands for host rock; V for infillings in vugs or fissures; the one with same number before $\mathrm{C}$ or $\mathrm{V}$ for paired samples.

gypsum. The gypsum of the lower and middle Cambrian formed fluid after redissolution and then migrated upward to the upper Permian to crystallize, which meant the fluids in the lower and upper Palaeozoic might have been interconnected with each other and the fluid sealing layer there had been destroyed, so the hydrocarbon preservation capacity of the lower association (Z-S) might have been lost.

The ${ }^{87} \mathrm{Sr} /{ }^{86} \mathrm{Sr}$ of limestone of the upper Permian was between $0.7070-0.7071$ and that of calcite vein infilling in fissures between $0.7074-0.7075$ (Table 1). The ${ }^{87} \mathrm{Sr} /{ }^{86} \mathrm{Sr}$ of host rocks was within that of contemporary normal seawater (between 0.7067-0.7076, McArthur et a1, 1994), which meant the host rocks were not or only slightly transformed. Though the ${ }^{87} \mathrm{Sr} /{ }^{86} \mathrm{Sr}$ of calcite was close to that of seawater in the same age of host rocks, the ${ }^{87} \mathrm{Sr} /{ }^{86} \mathrm{Sr}$ of veins was a little higher than that of host rocks $\left(\Delta^{87} \mathrm{Sr} /{ }^{86} \mathrm{Sr}_{\mathrm{v}-\mathrm{c}}=0.0004\right.$, Table 1), which indicated that the fluid forming calcite should chiefly come from the upper Permian themselves and a very small amount of allogenic fluids rich in strontium 87 was likely to have mixed to make the strontium isotope ratio of the veins a little higher than the host rocks. The obvious difference of carbon \& oxygen isotope ratios between the calcite veins and host rocks $\left(\Delta \delta^{13} \mathrm{C}_{\mathrm{v}-\mathrm{c}}=0.076 \%\right.$ o $-0.204 \% \mathrm{PDB}, \Delta \delta^{18} \mathrm{O}_{\mathrm{v}-\mathrm{c}}$ $=-2.79 \%-1.217 \%$ PDB $)$ (Table 1) justified from another perspective that the fluid was not directly from host rocks and included in part some allogenic fluids.

Due to the abundant methane inclusions in calcite infilling the fissures of the upper Permian and the source of fluid forming gypsum, the methane there probably mainly came from the hydrocarbon source rocks in the lower association. The infilling of fluid might have taken place during the gas window or post-gas window. The ${ }^{87} \mathrm{Sr} /{ }^{86} \mathrm{Sr}$ of gypsum and calcite infilling fissures and vugs of the upper Permian were close to the strontium isotope ratios of the marine carbonate of the Cambrian or Permian respectively, which demonstrated that while infilling, the fluid was not significantly diluted with meteoric water. It can be inferred that when the fluid containing hydrocarbon infilled, the reservoirs of the upper Permian had relatively good preservation conditions, which has been proved by drilling. The drilling of the Xinchang 2 well proved that the display of gas in the Huanglong Formation $\left(\mathrm{C}_{2} \mathrm{~h}\right)$ of 4179.1-4232.17 $\mathrm{m}$, the Qixia Formation $\left(\mathrm{P}_{1} \mathrm{q}\right)$ of $3957.47-3995 \mathrm{~m}$ and the Maokou Formation $\left(\mathrm{P}_{1} \mathrm{~m}\right)$ of 3641.88-3723.32 $\mathrm{m}$ suggested that the cracking gas in the paleo-gas pool of the lower association migrated vertically along faults or fissures and accumulated again in the strata of the Carboniferous and Permian where rather good preservation conditions were retained.

\subsection{Shizhu synclinorium zone}

The Jian 38 well and Long 8 well on this tectonic belt were chosen as key subjects for analysis. The tectonic location of the chosen wells is shown in Fig. 1b and the paleofluid characteristics of each well are described as follows:

\subsubsection{Jian 38 well}

The Jian 38 well was situated on the Jiannan structure of the Shizhu synclinorium zone. The lithology of the drilled $3^{\text {rd }}$ Member in the Feixianguan Formation of the lower Triassic $\left(\mathrm{T}_{1} \mathrm{f}^{3}\right)$ was deep grey micritics and calcarenite. Almost vertical fissures in which calcite veins of $2-8 \mathrm{~mm}$ wide infilled developed in limestone and black dry bitumen could be identified in some calcite veins. The fluid inclusions in calcite were about $3-12 \mu \mathrm{m}$ in size and gas-liquid phase saltwater and organic inclusions were the main type. Raman spectral analysis showed that the organic inclusions mainly consisted of liquid methane and some held a variable amount of H2S. From the component characteristics of the fluid inclusions and the coexistence of calcite and bitumen, it could be inferred that the infilling of fluid of this phase occurred during the post-gas window.

The ${ }^{87} \mathrm{Sr} /{ }^{86} \mathrm{Sr}$ of measured marine carbonate of the lower Triassic (0.7076) (Table 1) is the same as that of normal seawater of the early Triassic (0.7076) (Huang et al, 2005). This means that the host rocks were not influenced by 
allogenic fluid, largely retaining the strontium isotope ratios of the seawater when they were originally deposited. The similar ${ }^{87} \mathrm{Sr} /{ }^{86} \mathrm{Sr}$ of calcite in fissures $(0.7075-0.7076$, Table 1) to that of normal seawater of the early Triassic (0.7076) suggested the fluid forming the secondary calcite came from the host strata. Though the strontium isotope ratios of veins and host rocks tended to be very similar $\left(\Delta^{87} \mathrm{Sr} /{ }^{86} \mathrm{Sr}_{\mathrm{v}-\mathrm{c}}=0.0001\right.$, Table 1), the obvious difference of carbon \& oxygen isotope between veins and host rocks $\left(\Delta \delta^{13} \mathrm{C}_{\mathrm{v}-\mathrm{c}}=-0.427 \% \mathrm{PDB}-\right.$ $-0.208 \%$ PDB, $\Delta \delta^{18} \mathrm{O}_{\mathrm{v}-\mathrm{c}}=-2.008 \%$ PDB $--0.21 \% \mathrm{PDB}$; Table 1) showed that the fluid forming the calcite, could not have come from host rocks directly but from other positions in the host strata. In the meantime, because the infilling of fluid occurred during the post-gas window and the ${ }^{87} \mathrm{Sr} /{ }^{86} \mathrm{Sr}$ of formed calcite was the same as that of seawater in the host strata, it meant that the fluid system in reservoirs of lower Triassic was not diluted by meteoric water when fluid infilled and deposited. The Feixianguan Formation of the lower Triassic retained relatively good preservation conditions, which was also supported by practical drilling.

As described earlier, the saltwater fluid containing abundant methane inclusions in the Feixianguan Formation $\left(\mathrm{T}_{1} \mathrm{f}\right)$ came chiefly from the lower Triassic. The lack of hydrocarbon generation ability of the Feixianguan Formation itself shows the methane in calcite probably originated from the older underlying strata regionally. Practical drilling proved natural gas appeared from the Qixia Formation $\left(\mathrm{P}_{1} \mathrm{q}\right)$, the Maokou Formation $\left(\mathrm{P}_{1} \mathrm{~m}\right)$ to the Changxing Formation $\left(\mathrm{P}_{2} \mathrm{ch}\right)$ from the bottom up. Gas pools were found in the Feixianguan Formation of 3109-3164.5 m, the Jialingjiang Formation $\left(\mathrm{T}_{1} \mathrm{j}\right)$ of 2943-2956 m, 2971-2990 m, and 3011-3021 m. The level of gas increased gradually from the bottom up in general. It was inferred the natural gas in the Feixianguan Formation and the underlying Permian was homologous. The Permian was not the source of major hydrocarbon rocks in the research area; therefore, the majority of the natural gas occurring in the Permian might also have come from the underlying Palaeozoic.

The above analysis showed that, because the preservation conditions in the Palaeozoic itself were destroyed, the gas pools formed by thermal cracking of oil were destroyed, leaving the gas to migrate upward to the Permian, and then to keep migrating vertically to the Feixianguan Formation and the Jialingjiang Formation to accumulate again. When gas pools entered into the Feixianguang Formation, the saltwater fluid occurring there was affected by the inrush of gas to deposit calcite infilling.

What is worth noticing is that the Triassic Feixianguan Formation lacked saltwater fluid from the gas pools of the underlying Palaeozoic. This hints that the original gaswater interface might be beneath the Permian. The gas pool of reaccumulation should share the characteristic of high pressure to dissolve some natural gas into water to form liquid methane inclusions.

\subsubsection{Long 8 well}

The Long 8 well is situated on the Longjuba structure of the Shizhu synclinorium zone (Fig.1b). The lithology of the drilled Maokou Formation $\left(\mathrm{P}_{1} \mathrm{~m}\right)$ of the lower Permian and the $2^{\text {nd }}$ Member in the Changxing Formation $\left(\mathrm{P}_{2} \mathrm{ch}^{2}\right)$ of the upper Permian is grey to dark grey micrite. High dip angle fissures $\left(60^{\circ}-90^{\circ}\right)$ infilled with calcite developed. The measurement of fluid inclusions and Raman spectral analysis suggested that the fluid inclusions of calcite infilling in fissures of both the Maokou Formation and the Changxing Formation mainly belonged to gas-liquid phase saltwater inclusions and more liquid-phase $\mathrm{CH}_{4}-\mathrm{H}_{2} \mathrm{~S}$ inclusions with average temperature of $135-201^{\circ} \mathrm{C}$ and $132-168^{\circ} \mathrm{C}$ respectively. The average formation temperature of the fluid inclusions as well as the abundant $\mathrm{CH}_{4}-\mathrm{H}_{2} \mathrm{~S}$ phases in them demonstrate that the fluid infilling of this phase should occur during or after thermal cracking gas formation (post-gas window).

The ${ }^{87} \mathrm{Sr} /{ }^{86} \mathrm{Sr}$ of calcite veins in different depths and strata was 0.7071 . The same fluid inclusion characteristics and close temperature of all veins meant the infilling fluid was the same in different strata. Research indicates that the ${ }^{87} \mathrm{Sr} /{ }^{86} \mathrm{Sr}$ of normal seawater of the early and late Permian was 0.7076 0.7082 and $0.7067-0.7076$ respectively (Shi et al 2002). Both the distinctive lower ${ }^{87} \mathrm{Sr} /{ }^{86} \mathrm{Sr}$ of calcite infilled in fissures in the Maokou Formation than that of its host strata and the obvious difference of carbon \& oxygen isotope between the veins and host rocks $\left(\Delta \delta^{13} \mathrm{C}_{\mathrm{v}-\mathrm{c}}=0.238 \% \mathrm{PDB}-0.291 \% \mathrm{PDB}\right.$, $\Delta \delta^{18} \mathrm{O}_{\mathrm{v}-\mathrm{c}}=-0.726 \% \mathrm{PD}--0.419 \% \mathrm{PDB}$; Table 1) indicated the fluid was allogenic, poor in strontium 87 . The similar ${ }^{87} \mathrm{Sr} /{ }^{86} \mathrm{Sr}$ of calcite infilled in fissures of the upper Permian to that of contemporary seawater of the host rocks showed the fluid came from the upper Permian. However, the difference of $\Delta \delta^{13} \mathrm{C}_{\mathrm{v}-\mathrm{c}}(-0.339 \% \mathrm{PDB})$ and $\Delta \delta^{18} \mathrm{O}_{\mathrm{v}-\mathrm{c}}(-0.182 \% \mathrm{PDB})$ (Table 1) between veins and host rocks hinted that the fluid came from the Permian but not from adjacent host rocks directly. However, it should still be classified as authigenic. The same ${ }^{87} \mathrm{Sr} /{ }^{86} \mathrm{Sr}$ of the fluid of the lower Permian and the overlying upper Permian suggests that the fluid interconnected between the upper and lower Permian and flowed from top to bottom. The strontium isotope characteristics of infilled veins showed that the fluid was not affected by meteoric water when infilling, namely, surface water did not connect with the fluid in reservoir, which hinted that relatively good preservation conditions remained when fluid infilled. The drilling showed that the gas pool was met in the Maokou Formation of 4742.4-4849 m, which also testified the good preservation conditions were retained in the Permian of this well. From the evidence of oil and gas of the Long 5 well and the Long 10 well to the NE of Long 8 well, gas could be found in both these two wells in Jialingjiang Formation. All these three wells once experienced gas infilling and accumulation with relatively good preservation conditions.

The strontium isotope characteristics showed the fluid in the Permian largely came from the upper Permian. Raman spectral analysis of fluid inclusions revealed these fluids were very rich in liquid methane and practical drilling also proved cracking gas accumulated in the Permian. Thermal cracking gas could not possibly have come from the host rocks of the Permian while it is likely to be only from the paleo-gas pool of the underlying Silurian, which denoted that thermal cracking gas was characterized by vertical cross-strata flow. The saltwater fluid flowed downward in the Permian and 

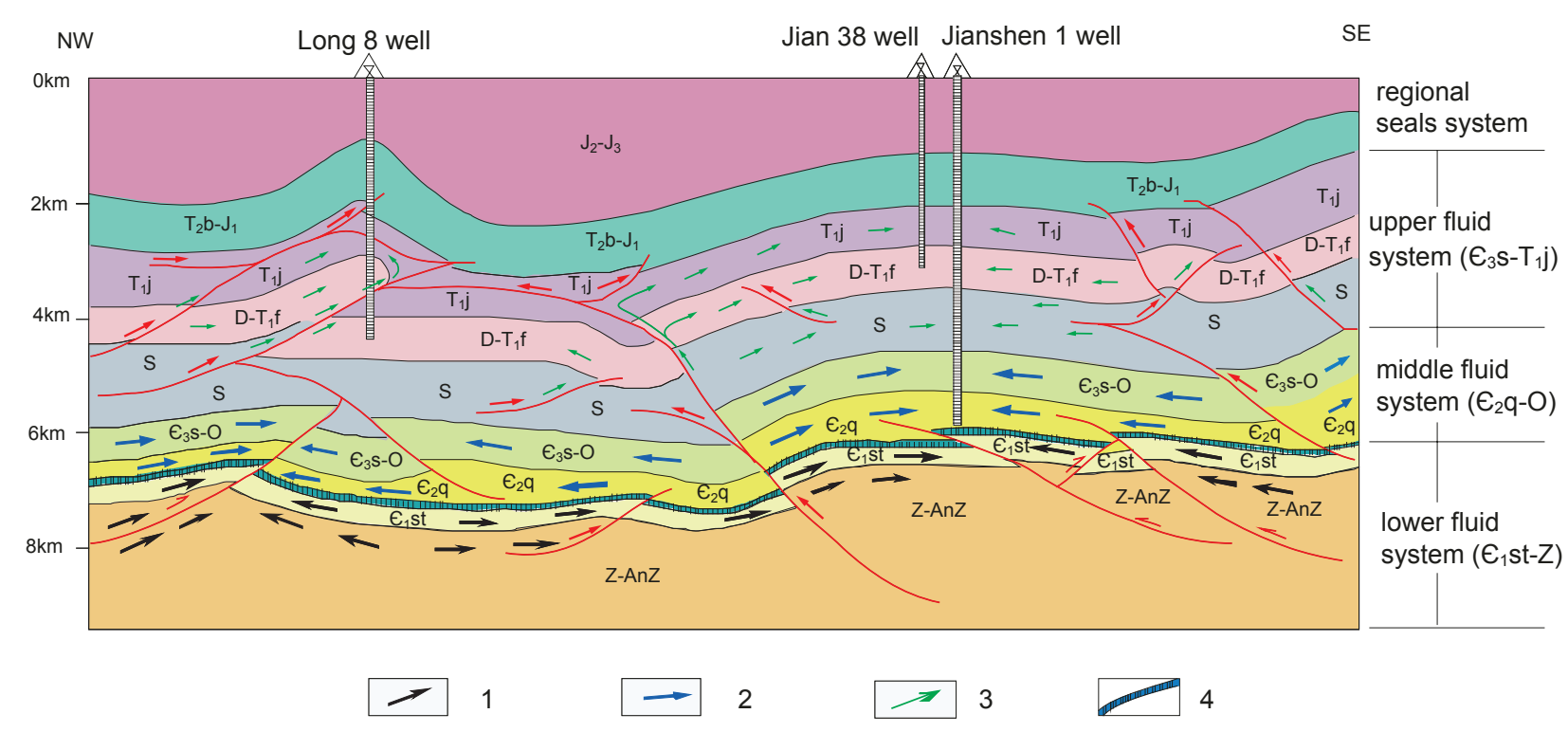

Fig. 2 Path of fluid migration in Shizhu synclinorial zone

1, 2, 3-Direction of fluid migration in lower, middle and upper fluid system respectively; 4-Gypsum

formed a local fluid circulation. The lack of saltwater fluid of the underlying paleo-reservoir or gas pool in the Permian meant the Triassic above the gas pool provided good sealing capacity.

\subsubsection{Path of fluid migration and preservation conditions}

From the analysis of fluid in the Jian 38 well and the Long 8 well above, the fluid migrational path in Shizhu synclinorium zones thought to be as shown in Fig.2. Fluid exchange occurred between the middle and upper fluid system. The fluid in the middle migrated to the upper system in which atmospheric freshwater seldom infilled and the Permian and Triassic in the upper-middle association had better sealing capacity and preservation conditions. Fluid exchange seldom occurred between the upper-middle and the lower fluid systems, which was a relatively isolated fluid system. Relatively good preservation conditions were retained in the Dengying Formation of the Sinian and the lower Cambrian in the lower association. The fluid migration path showed the preservation conditions in this tectonic belt were good and the fluid sealing system had a two-layer configuration forming two independent preservation units with good preservation conditions separately in the upper and the lower. Both the Permian and Triassic in the upper preservation units and the Dengying Formation of the Sinian and the lower Cambrian in the lower preservation units had good preservation conditions.

\section{Paleo-fluid and its preservation conditions in west Hunan and Hubei}

\subsection{Central anticlinorium zone}

The representative Li 1 well, Li 2 well and the outcrop samples of the Baiguoba profile in this tectonic belt were taken as examples. The analyzed well positions and the outcrop sample location are shown in Fig.1b.

\subsubsection{Li 1 well}

The Li 1 well is situated in the Lizixi structure of the central anticlinorium zone. The host rock of the Sanyoudong Formation $\left(\in_{3} \mathrm{~s}\right)$ of the upper Cambrian at $245 \mathrm{~m}$ and 488.3 $\mathrm{m}$ was dolomite, the ${ }^{87} \mathrm{Sr} /{ }^{86} \mathrm{Sr}$ of which were 0.7094 and 0.7093 respectively and the vein infilled in fissures of host rocks was calcite, the ${ }^{87} \mathrm{Sr} /{ }^{86} \mathrm{Sr}$ of which was both 0.7092 . The slight difference of strontium isotope between vein and host rocks $\left(\Delta^{87} \mathrm{Sr} /{ }^{86} \mathrm{Sr}_{\mathrm{v}-\mathrm{c}}=-0.0001--0.0002\right.$, Table 1) as well as the similar ${ }^{87} \mathrm{Sr} /{ }^{86} \mathrm{Sr}$ of vein and host rocks and that of normal seawater of the late Cambrian (0.7091-0.7093, Denison et al, 1998) suggested that the fluid forming calcite veins came from the upper Cambrian. The distinctive difference of oxygen isotope $\left(\Delta \delta^{18} \mathrm{O}_{\mathrm{v}-\mathrm{c}}=-3.804 \% \mathrm{PDB}--3.53 \% \mathrm{PDB}\right)$ and carbon isotope $\left(\Delta \delta^{13} \mathrm{C}_{\mathrm{v}-\mathrm{c}}=-1.669 \% \mathrm{PDB}--1.58 \% \mathrm{PDB}\right)$ (Table 1) hinted that the fluid forming the calcite veins, although classified as authigenic, was not directly from the host rocks but from elsewhere in the upper Cambrian.

The similar ${ }^{87} \mathrm{Sr} /{ }^{86} \mathrm{Sr}$ of calcite veins (0.7086) infilled in fissures in $2878 \mathrm{~m}$ of the Shipai Formation of the lower Cambrian $\left(\in_{1} \mathrm{sp}\right)$ to that of seawater at the time of deposition of the Dengying Formation (0.7083) (Zhang, 1995) meant the fluid forming calcite veins in the fissures of the lower Cambrian came from dissolution of carbonate in the underlying Dengying Formation, which demonstrates that the fluid isolating intervals between the lower Cambrian and the Dengying Formation were destroyed and the paleo-fluid migrated from bottom to top.

The above analysis indicated the fluids of the lower Cambrian $\left(\in_{1} \mathrm{sp}\right)$ and the upper Cambrian $\left(\in{ }_{3} \mathrm{~s}\right)$ were of different origins, which suggests that the upper and lower fluid systems were not connected with a fluid isolating interval in the middle. The same ${ }^{87} \mathrm{Sr} /{ }^{86} \mathrm{Sr}$ of veins of the upper Cambrian as that of seawater of host rocks suggested the strata lacked meteoric water rich in strontium 87 and the upper and lower Cambrian of this well position had good 
preservation conditions. The display of gas in of 3085-3124 $\mathrm{m}$ and 3131-3136 $\mathrm{m}$ in the Li 1 well of the Shipai Formation $\left(\in_{1} \mathrm{sp}\right)$ suggested that gas pool had also accumulated.

\subsubsection{Li 2 well}

The Li 2 well, developed fissures dipping at $85^{\circ}$, is located in the Lizixi structure of the central anticlinorium zone. The lithology of the drilled lower Cambrian and Dengying Formation was mainly dolomite. The infillings in fissures of the Cambrian and Dengying Formation were dolomite and calcite respectively (Table 1 ).

Both the ${ }^{87} \mathrm{Sr} /{ }^{86} \mathrm{Sr}$ of dolomites infilled in fissures around $2444.42 \mathrm{~m}$ of the Shipai Formation of the lower Cambrian $\left(\in_{1} \mathrm{sp}\right)$ and that of host rocks (dolomites) were 0.7096 which was close to that of the seawater of the early Cambrian. It showed that these fluids chiefly came from the lower Cambrian. Though the strontium isotope ratio of host rocks and veins are the same $\left(\Delta^{87} \mathrm{Sr}^{86} \mathrm{Sr}_{\mathrm{v}-\mathrm{c}}=0\right)$, the carbon \& oxygen isotope $\left(\Delta \delta^{13} \mathrm{C}_{\mathrm{v}-\mathrm{c}}=0.125 \% \mathrm{PDB}, \Delta \delta^{18} \mathrm{O}_{\mathrm{v}-\mathrm{c}}=1.336 \% \mathrm{PDB}\right)$ (Table 1) did not. It meant that the fluid forming the dolomite veins did not come from host rocks directly, but from other parts of the lower Cambrian but are still classified as authigenic.

Both the ${ }^{87} \mathrm{Sr} /{ }^{86} \mathrm{Sr}$ of dolomite around $3396.70 \mathrm{~m}$ of the Sinian $\left(\mathrm{Z}_{2} \mathrm{dy}^{3}\right)$ and $3464.52 \mathrm{~m}$ of $\left(\mathrm{Z}_{2} \mathrm{dy}^{1}\right)$ were 0.9074 and that of calcite veins infilled in fissures were 0.7097 (Table 1). The obviously higher value of strontium isotope ratios of both host rocks and veins than that of contemporary normal seawater of the Sinian (0.7083) shows the fluid forming calcite veins was allogenic, richer in strontium 87 . The different strontium as well as carbon \& oxygen isotope ratios between this fluid and host rocks allowed the host rocks and the fluid to undergo isotope exchange to increase the value of strontium isotope ratio of the host rocks. However, this kind of exchange did not achieve complete equilibrium and resulted in the apparent difference of strontium as well as carbon \& oxygen isotope ratios between veins and host rocks $\left(\Delta^{87} \mathrm{Sr} /{ }^{86} \mathrm{Sr}_{\mathrm{v}-\mathrm{c}}=0.0003\right.$, $\left.\Delta \delta^{13} \mathrm{C}_{\mathrm{v}-\mathrm{c}}=-2.971 \%{ }_{0} \mathrm{PDB}, \Delta \delta^{18} \mathrm{O}_{\mathrm{v}-\mathrm{c}}=-6.432 \%{ }_{0} \mathrm{PDB}\right)$ (Table 1).

The very close ${ }^{87} \mathrm{Sr} /{ }^{86} \mathrm{Sr}$ of calcite infilled in fissures in the Dengying Formation of the Sinian to that of dolomite of the overlying lower Cambrian suggested the fluid infilled in the Dengying Formation should be formed by dissolution of carbonate strata of the overlying lower Cambrian. It was characterized by vertical and cross-strata flow from bottom to top and the two fluid systems might be interconnected.

\subsubsection{Baiguoba}

The lithology of the Haozituo Formation $\left(\in{ }_{3} \mathrm{hz}\right)$ of the upper Cambrian in the Baiguoba was micritic limestone and calcite veins were infilled in fissures. The ${ }^{87} \mathrm{Sr} /{ }^{86} \mathrm{Sr}$ of limestone and calcite veins was 0.7083 and 0.7116 (Table 1) respectively. The ${ }^{87} \mathrm{Sr} /{ }^{86} \mathrm{Sr}$ of the normal seawater of the late Cambrian ranged from 0.7089 to 0.7092 (Denison et al 1998). The obviously lower ${ }^{87} \mathrm{Sr} /{ }^{86} \mathrm{Sr}$ of the host rocks than that of contemporary normal seawater meant the host rocks were modified by the fluid low in strontium 87 . While the ${ }^{87} \mathrm{Sr} /{ }^{86} \mathrm{Sr}$ of infillings in fissures of paired samples was clearly higher than that of contemporary normal seawater, which indicated the fluid forming veins was rich in strontium 87 . The distinctive different value of strontium isotope between veins and host rocks $\left(\Delta^{87} \mathrm{Sr} /{ }^{86} \mathrm{Sr}_{\mathrm{v}-\mathrm{c}}=0.0033\right)$ hinted that the fluid forming veins were allogenic, rich in strontium 87 . The host rocks were not transformed by this strontium- 87 rich allogenic fluid, but affected by an early fluid depleted in strontium 87 to result in relatively low strontium isotope ratios in the host rocks.

The close ${ }^{87} \mathrm{Sr} /{ }^{86} \mathrm{Sr}$ of calcite infilled in the Cambrian to that of calcite infilled in vugs in the Dengying Formation of the Sinian in the Cili-Nanshanping described later declared both of them derived from homologous fluids rich in strontium 87. The successive generation relationships of minerals in the Cili-Nanshanping were: bitumen $\rightarrow$ calcite $\rightarrow$ quartz from their infilling relationship. In the profile of the Cili-Nanshanping, the calcite analyzed should come into being after the thermal cracking of oil and the fluid infilling should occur during the post-gas window. It could be inferred that the fluid forming calcite in fissures on the profile of the Baiguoba came from the underlying Sinian and infilling of these fluids took place after the thermal cracking of oil (post-gas window) according to the same strontium isotope characteristics of calcite in the fissures on the profile of both the Baiguoba and Cili-Nanshanping as well as their time sequence with thermal cracking gas.

The analysis above demonstrated that after thermal cracking of oil, the fluid system in both the Cambrian and the underlying Sinian had interconnected; namely, the destruction of fluid isolating intervals between the Sinian and Cambrian contributed to the transformational flow of fluid rich in strontium 87 of the underlying Sinian from bottom to top.

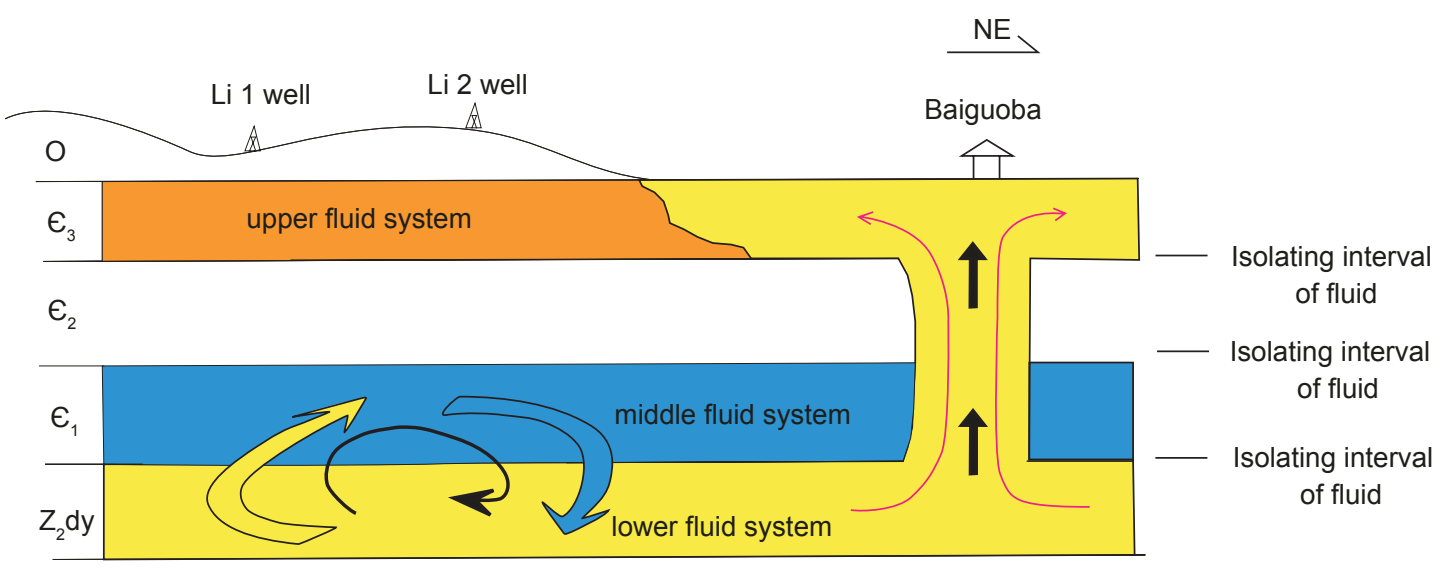

Fig.3 Path of fluid migration in the central anticlinorium zone (Arrow represents direction of fluid migration) 


\subsubsection{Path of fluid migration and preservation conditions}

After analysis of samples from the Li 1 and Li 2 wells, and the Baiguoba surface samples, the migration path of the fluid in the central anticlinorium zone could be estimated as shown in Fig. 3. The fluid systems in the bottom and the middle were interconnected in the $\mathrm{Li} 1$ well and $\mathrm{Li} 2$ well. The fluid in the Li 1 well migrated from bottom to top while that in the Li 2 well went in the opposite direction to form a fluid cycling system. However, the existence of isolating intervals between the fluid systems on the top and in the middle and the bottom allowed the good preservation conditions of the underlying lower Cambrian to remain. In the Baiguoba area, all fluid isolating intervals were destroyed and the fluid systems in the bottom and the top interconnected as the preservation conditions of the lower Cambrian had been destroyed. The intensity of the destruction of fluid isolating intervals in the lower association was increasing while the preservation conditions are worse towards the NE from the $\mathrm{Li}$ 1 well to Baiguoba spatially.

\subsection{Yidu-Hefeng anticlinorium zone}

The Laifeng-Xianfeng profile on this anticlinorium zone was chosen as an example. The sampling point and analysis results were shown in Fig. 1 and Table 1 respectively.

The ${ }^{87} \mathrm{Sr} /{ }^{86} \mathrm{Sr}$ of calcarenite of the upper Ordovician $\left(\mathrm{O}_{3}\right)$ and calcite veins infilled in fissures was 0.7092 and 0.7116 respectively, which were clearly higher than the ${ }^{87} \mathrm{Sr} /{ }^{86} \mathrm{Sr}$ of contemporary normal seawater (between 0.7078-0.7088; Denison et al, 1998). It meant that the fluid forming the veins was allogenic, richer in strontium 87 and the host rocks were so reformed by this fluid that their ${ }^{87} \mathrm{Sr} /{ }^{86} \mathrm{Sr}$ deviated from the ${ }^{87} \mathrm{Sr} /{ }^{86} \mathrm{Sr}$ of normal seawater. The ${ }^{87} \mathrm{Sr} /{ }^{86} \mathrm{Sr}$ of limestone in the Guniutan Formation $\left(\mathrm{O}_{2} \mathrm{~g}\right)$ of the middle Ordovician was between $0.7095-0.7097$ and that of infillings in fissures remained in 0.7116 . The obviously higher ${ }^{87} \mathrm{Sr} /{ }^{86} \mathrm{Sr}$ of both host rocks and infillings in fissures than that of contemporary normal seawater (0.7088-0.7090; Denison et al, 1998) said that the fluid forming calcite veins was allogenic, rich in strontium 87 from outside of the mid-upper Ordovician. The isotope exchange occurred between fluid and host rocks, increasing the strontium isotope ratio of the host rocks. The obviously higher $\Delta \Delta^{87} \mathrm{Sr} /{ }^{86} \mathrm{Sr}_{\mathrm{v}-\mathrm{c}}(0.0019-0.0021)$ (Table 1) between veins and host rocks hinted the isotope exchange between fluid and host rocks did not achieve equilibrium.

The host rocks of the lower Cambrian $\left(\in_{1}\right)$ were dolomitic limestones with dolomite infilling in fissures. The close ${ }^{87} \mathrm{Sr} /{ }^{86} \mathrm{Sr}$ of host rocks to that of contemporary seawater, the distinctive higher ${ }^{87} \mathrm{Sr} /{ }^{86} \mathrm{Sr}$ of dolomite veins than that of contemporary seawater along with the strontium isotope difference $\left(\Delta^{87} \mathrm{Sr} /{ }^{86} \mathrm{Sr}_{\mathrm{v}-\mathrm{c}}=0.0028\right.$, Table 1) between veins and host rocks indicated together that the fluid forming the veins was allogenic rich in strontium 87. Isotope exchange seldom occurred between fluid and host rocks with inconspicuous water-rock reactions and the host rocks retained more of their original strontium isotope characteristics.

In the carbonate paired samples taken from the LaifengXianfeng profile, the ${ }^{87} \mathrm{Sr} /{ }^{86} \mathrm{Sr}$ of veins centered on 0.7114 0.7116 , which was very close to that of the fluid (0.7114) infilling in vugs in the Dengying Formation of the Sinian in the Cili-Nanshanping (Table 1). It meant they were homologous allogenic fluids rich in strontium 87. According to the generation relationships of minerals on the profile in the Cili-Nanshanping, the infilling of these fluids occurred after the accumulation of natural gas (post-gas window). If these fluids were the same as those in reservoirs of the overlying Cambrian and Ordovician, it was implied that the early natural gas accumulated in the Sinian and Cambrian and the fluid isolating intervals of the Sinian/Cambrian as well as those of the mid-lower Ordovician were destroyed without any preservation capacity being retained.

\subsection{Sangzhishimen anticlinorium zone}

\subsubsection{Cili-Nanshanping profile}

The lithology of the Dengying Formation $\left(Z_{2} d y\right)$ on the Cili-Nanshanping profile is grey micritic limestone and bitumen $\rightarrow$ calcite $\rightarrow$ quartz infilled in vugs in turn. The second generation calcite in vugs was chosen to analyze the isotope ratio (Table 1). The higher ${ }^{87} \mathrm{Sr} /{ }^{86} \mathrm{Sr}$ of both calcite (0.7114) and dolomite host rocks (0.7103) than that of contemporary normal seawater $(0.7083$ on average)(Zhang, 1995) meant the fluid forming the veins was allogenic, rich in strontium 87 which violently transformed the host rocks to make the strontium isotope ratios of the fluid and host rocks approach equilibrium $\left(\Delta^{87} \mathrm{Sr} /{ }^{86} \mathrm{Sr}_{\mathrm{v}-\mathrm{c}}=0.0001\right.$, Table 1$)$. The generation relationships between bitumen and the analyzed calcite reflected that the infilling of these fluids mostly occurred during the post-gas window.

\subsubsection{Sangzhi-Hongjiaguan-Wudaoshui profile}

The representative sample on this profile was taken from the Honghuayuan Formation $\left(\mathrm{O}_{1} \mathrm{~h}\right)$ of the Ordovician and the Sanyoudong Formation $\left(\epsilon_{3} \mathrm{~S}\right)$ of upper Cambrian. The ${ }^{87} \mathrm{Sr} /{ }^{86} \mathrm{Sr}$ of calcarenite in the Honghuayuan Formation of the lower Ordovician and calcite infilled in fissures was 0.7096 and 0.7115 respectively (Table 1 ). The research done by McArthur et al (1994) showed that the ${ }^{87} \mathrm{Sr} /{ }^{86} \mathrm{Sr}$ of normal paleo-seawater of the early Ordovician ranged from 0.7088 to 0.7092 , which was obviously lower than that of host rocks and veins. The obvious strontium isotope difference between host rocks and veins $\left(\Delta^{87} \mathrm{Sr}^{86} \mathrm{Sr}_{\mathrm{v}-\mathrm{c}}=0.0019\right.$, Table 1) indicated that the fluid forming the veins was allogenic rich in strontium 87 which transformed the host rocks. Calcite or dolomite was infilled in fissures in the Sanyoudong Formation $\left(\in_{3} s\right)$ of the upper Cambrian, among which a little fine bitumen could be detected in the SHW-7V sample of a calcite vein. The ${ }^{87} \mathrm{Sr} /{ }^{86} \mathrm{Sr}$ of dolomite and the veins of infillings in fissures in the Sanyoudong Formation were between 0.7095-0.7099 and $0.7114-0.7116$ (Table 1) respectively. The veins were clearly richer than the host rocks in strontium 87 . The distinctively higher ${ }^{87} \mathrm{Sr} /{ }^{86} \mathrm{Sr}$ of both the host rocks and the infillings in fissures than that of the normal paleo-seawater of the late Cambrian (0.7089-0.7092, Denison et al, 1998) showed that the fluid infilled in the fissures of the Sanyoudong Formation was allogenic, rich in strontium 87.

As shown in Table 1 the ${ }^{87} \mathrm{Sr} /{ }^{86} \mathrm{Sr}$ of calcite or dolomite infilled in fissures of the lower Ordovician and the upper Cambrian centered on 0.7114-0.7116 (Table 1) which was 
close to that of the calcite $(0.7114)$ in vugs of the Sinian in the Cili-Nanshanping, showing that the infilling fluids in these three different intervals were homologous. The fluid from the same source of both the lower Ordovician and the upper Cambrian hints that the fluid of these two intervals was interconnected by vertical migration across strata. The fine bitumen contained in the analyzed sample meant the infilling of this stage's fluid occurred during the post-gas window. Providing favorable passage for migration of oil/gas and fluid, the interconnection of fissures in host rocks resulted in the destruction of preservation conditions in the Sanyoudong Formation of the underlying upper Cambrian.

\subsubsection{Path of fluid migration}

The path of fluid migration was shown in Fig.4 based on geochemical traces of fluid in different intervals on this tectonic belt. All fluids in the Dengying Formation of the Sinian, Cambrian and Ordovician belonged to homologous fluid rich in strontium 87 . The fluid in different intervals was interconnected and the fluid isolating interval in the lower association had been destroyed. The infilling of this stage's fluid occurred after the thermal cracking of oil, which demonstrated the preservation conditions of the lower association had been destroyed with the total loss of the original gas pool.

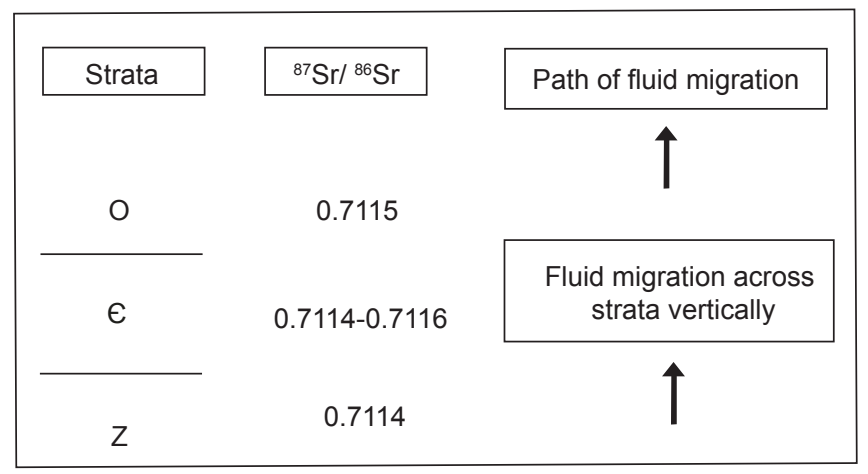

Fig. 4 Path of fluid migration in synclinorium zone from Sangzhi to Shimen

\section{Comprehensive evaluation of preservation condition}

The isotope geochemistry trace for paleo-fluid in different tectonic units discussed above suggested that the fluid isolating intervals in the lower association, except the Shizhu synclinorium, had been entirely destroyed. Both paleo-fluid and thermal cracking gas migrated across the previously isolating intervals upward to the middle association of the Carboniferous and the Permian strata and the upper association of the Feixianguan Formation and the Jialingjiang Formation to deposit or re-accumulate. Hence, the spatial distribution of marine carbonate of the Carboniferous-Triassic becomes a key factor to evaluate preservation conditions.

The property of formation water is another important parameter to evaluate the preservation condition of reservoirs (Ma et al, 2004; Lou et al, 2006; Hu et al, 2007) and also a direct indication of today's preservation condition. The degree of mineralization and types of formation water in the representative wells located in different tectonic units are listed in Table 2. The locations of wells in Table 2 are marked in Fig.1b. The formation water in the Carboniferous - Feixianguan Formation located in the Fangdoushan anticlinorium and the Shizhu synclinorium are characterized by a high degree of mineralization (91.5-134.8 g/L), low $\mathrm{r}\left(\mathrm{Na}^{+}\right) / \mathrm{r}\left(\mathrm{Cl}^{-}\right)(0.70-0.94)$ and burial water of $\mathrm{CaCl}_{2}$ type (Table 2), which means the both tectonic zones are of good preservation condition. The preservation condition in southern Qiyueshan anticlinorium is worse because underground water from the Carboniferous, Permian and Feixianguan Formation in Yan 1 well and Juan 1 well was very low salinity, whose degree of mineralization was lower than $10 \mathrm{~g} / \mathrm{L}, \mathrm{r}\left(\mathrm{Na}^{+}\right) / \mathrm{r}\left(\mathrm{Cl}^{-}\right)(>1)$; mixture of different water types including $\mathrm{Na}_{2} \mathrm{SO}_{4}, \mathrm{NaHCO}_{3}$ and $\mathrm{CaCl}_{2}$ appeared and underground water was very low in chloride (Table 2 ). Around the drilling located other tectonic zones, worse preservation condition can be defined by characteristics of formation water from the Sinian, the Cambrian and part of the Silurian and the Ordovician with low degree of mineralization, high $\mathrm{r}\left(\mathrm{Na}^{+}\right) / \mathrm{r}\left(\mathrm{Cl}^{-}\right)$and water types of $\mathrm{Na}_{2} \mathrm{SO}_{4}$ or $\mathrm{NaHCO}_{3}$ (Table 2).

In order to evaluate the preservation conditions for different tectonic units reliably and objectively, the evaluation based on paleo-fluids and property of the current formation water, spatial distribution of marine carbonate of the CarboniferousJialingjiang Formation, tectonic denudation and intensity of deformation will be considered comprehensively. The preservation condition for the research area can be divided into four grades: the highest, good, inferior and worst. The spatial distribution of preservation units with different preservation conditions is given in Fig.5.

\section{Conclusion}

1) The preservation conditions of oil/gas could be evaluated effectively by the geochemical trace of key paleo-fluids.

2) The Shizhu synclinorium zone and the Fangdoushan anticlinorium zone are characterized by the best preservation conditions in the central Yangtze. Three sets of fluid systems in the Shizhu synclinorium zone are identified, fluid exchange is missing between the upper, middle fluid system and the lower fluid system there and two independent preservation units are developed. Both the upper preservation unit consisting of the Permian and the Triassic and the lower preservation unit consisting of the Dengying Formation and the lower Cambrian are of good preservation condition.

3) In western Hubei and Hunan, preservation condition in the Huaguoping synclinorium zone is better than that in other tectonic units, where the fluids in the lower association migrated vertically across strata when the fluid isolating interval has been destroyed, regional seals including the Carboniferous, the Permian and the Triassic carbonate are absent and the preservation condition has been totally destroyed.

4) The upper Palaeozoic and the Mesozoic marine strata in composite synclines are still superior in hydrocarbon preservation condition. The preservation condition obviously improves from the western Jiangxi and Hunan to the western 
Table 2 Degree of mineralization and type of formation water in different tectonic units (After Ma et al, 2004)

\begin{tabular}{|c|c|c|c|c|c|c|}
\hline $\begin{array}{c}\text { Tectonic } \\
\text { unit }\end{array}$ & $\begin{array}{l}\text { Well } \\
\text { No. }\end{array}$ & strata & $\begin{array}{c}\text { Depth } \\
\mathrm{m}\end{array}$ & $\begin{array}{l}\text { Degree of mineralization } \\
\mathrm{g} / \mathrm{L}\end{array}$ & $\begin{array}{c}\mathrm{r}\left(\mathrm{Na}^{+}\right) / \\
\mathrm{r}\left(\mathrm{Cl}^{-}\right)\end{array}$ & $\begin{array}{c}\text { Type of formation } \\
\text { water }\end{array}$ \\
\hline \multirow{3}{*}{$\begin{array}{l}\text { Fangdoushan anticlinorium } \\
\text { Zone }\end{array}$} & Cizhu 1 well & $\mathrm{C}_{2}$ & & 124.6 & 0.77 & $\mathrm{CaCl}_{2}$ \\
\hline & Maan 1well & $\mathrm{C}_{2}$ & & 134.8 & 0.81 & $\mathrm{CaCl}_{2}$ \\
\hline & Yangdu 3 well & $\mathrm{T}_{1} \mathrm{f}$ & & 66.8 & 0.94 & $\mathrm{CaCl}_{2}$ \\
\hline \multirow{3}{*}{$\begin{array}{l}\text { Shizhu synclinorium } \\
\text { zone }\end{array}$} & Long 8 well & $\mathrm{P}_{1} \mathrm{q}, \mathrm{C}_{2}$ & & 130.5 & 0.7 & $\mathrm{CaCl}_{2}$ \\
\hline & Jian 42 well & $\mathrm{C}$ & $4268-4299$ & 91.5 & 0.75 & $\mathrm{CaCl}_{2}$ \\
\hline & Jian 31 well & $\mathrm{P}_{2} \mathrm{C}$ & $2968-3072$ & 133.2 & 0.91 & $\mathrm{CaCl}_{2}$ \\
\hline \multirow{4}{*}{$\begin{array}{l}\text { Qiyueshan anticlinorium } \\
\text { zone }\end{array}$} & \multirow{2}{*}{ Yan 1well } & $\mathrm{T}_{1} \mathrm{f}$ & $2109-2160$ & 2.43 & 10.8 & $\mathrm{NaHCO}_{3}$ \\
\hline & & $\mathrm{P}_{2}$ & $2493-2534$ & 8.8 & 0.93 & $\mathrm{CaCl}_{2}$ \\
\hline & \multirow{2}{*}{ Juan 1well } & $\mathrm{T}_{1} \mathrm{f}$ & $2224-2417$ & 1.43 & 5.6 & $\mathrm{Na}_{2} \mathrm{SO}_{4}$ \\
\hline & & $\mathrm{P}_{2} \mathrm{ch}$ & $2675-2902$ & 2.74 & 1.5 & $\mathrm{Na}_{2} \mathrm{SO}_{4}$ \\
\hline $\begin{array}{c}\text { Lichuan synclinorium } \\
\text { zone }\end{array}$ & Yu 1well & $\mathrm{Z}_{2} \mathrm{dy}$ & $4440-4552$ & 14 & 11 & $\mathrm{NaHCO}_{3}$ \\
\hline \multirow{3}{*}{$\begin{array}{l}\text { Central anticlinorium } \\
\text { zone }\end{array}$} & Cha 1well & $\in_{1} \mathrm{~s}$ & 1372 & 27 & 32 & $\mathrm{Na}_{2} \mathrm{SO}_{4}$ \\
\hline & Ecan 1 well & $\mathrm{Z}_{1} \mathrm{n}$ & $2978-2990$ & 6.8 & 3.8 & $\mathrm{NaHCO}_{3}$ \\
\hline & Li 2 well & $\in_{2} \mathrm{q}$ & 1725.6 & 3.8 & 3.8 & $\mathrm{Na}_{2} \mathrm{SO}_{4}$ \\
\hline \multirow{3}{*}{$\begin{array}{l}\text { Huaguoping synclinorium } \\
\text { zone }\end{array}$} & \multirow{2}{*}{ He 2 well } & S & $528-549$ & 1.8 & 40 & $\mathrm{NaHCO}_{3}$ \\
\hline & & $\mathrm{O}_{1} \mathrm{~h}$ & $1278-1364$ & 12 & 9.9 & $\mathrm{Na}_{2} \mathrm{SO}_{4}$ \\
\hline & Xi 1well & $\in_{1 \mathrm{~S}}$ & $3594-3739$ & 8.9 & 4.1 & $\mathrm{NaHCO}_{3}$ \\
\hline \multirow{5}{*}{$\begin{array}{l}\text { Yidu-Hefeng anticlinorium } \\
\text { zone }\end{array}$} & \multirow{2}{*}{ Da 1well } & $\in_{2} \mathrm{q}$ & $743-768$ & 4.8 & 2.3 & $\mathrm{Na}_{2} \mathrm{SO}_{4}$ \\
\hline & & $\in_{1} \mathrm{~S}$ & $1063-1065$ & 5.1 & 2.2 & $\mathrm{Na}_{2} \mathrm{SO}_{4}$ \\
\hline & Mao 3 well & $\in-\mathrm{Z}$ & $429-485$ & 1.1 & 4.8 & $\mathrm{NaHCO}_{3}$ \\
\hline & Xian 2 well & $\in_{1}$ & $720-740$ & 14 & 29 & $\mathrm{NaHCO}_{3}$ \\
\hline & Yi 4 well & $\mathrm{Z}_{2} \mathrm{dy}$ & $670-680$ & 5.2 & 2.1 & $\mathrm{Na}_{2} \mathrm{SO}_{4}$ \\
\hline
\end{tabular}

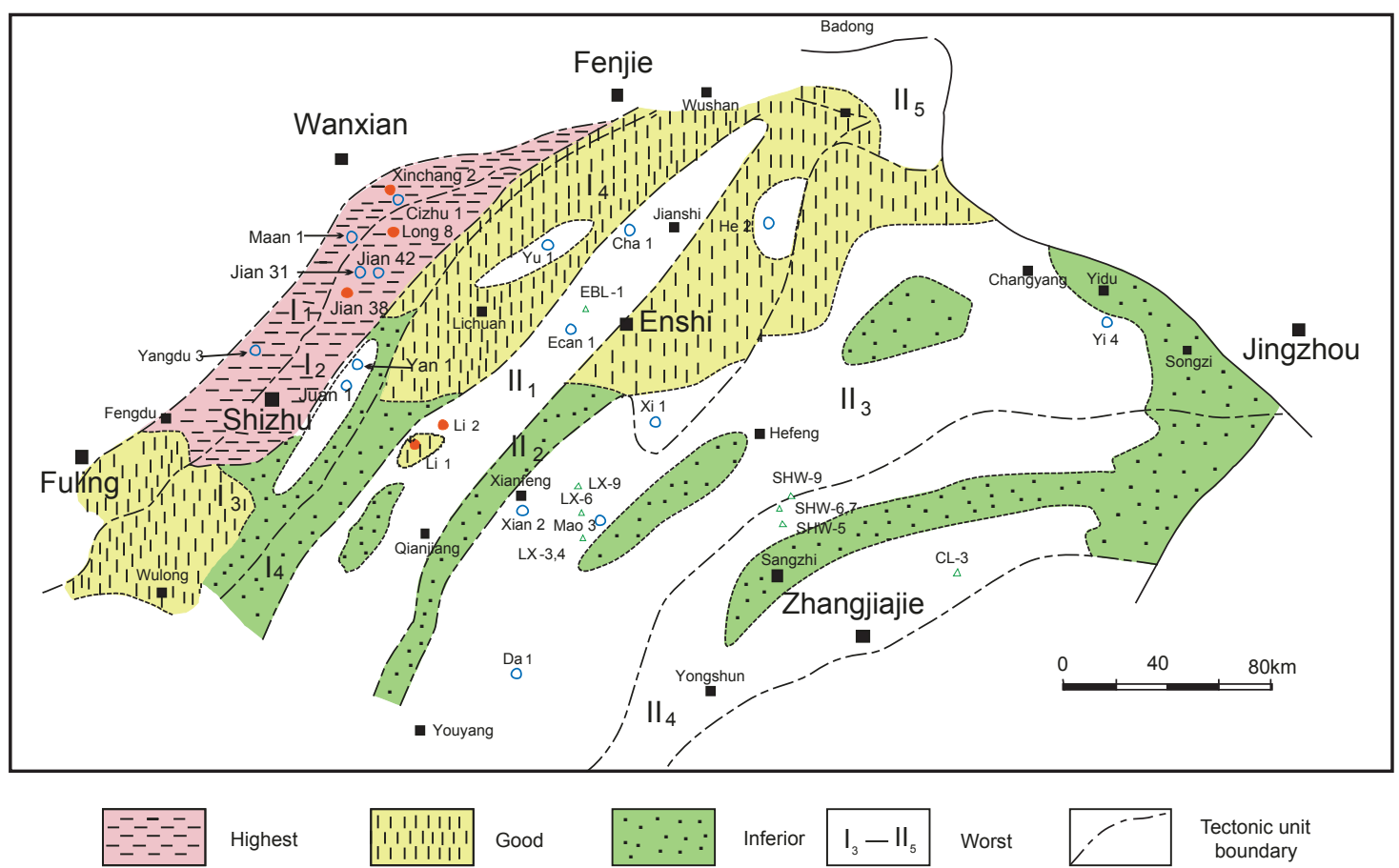

Fig. 5 Spatial distribution characteristic of preservation unit in $\mathrm{I}_{1}-\mathrm{II}_{5}$ 
Hubei \& eastern Chongqing on the whole.

\section{Acknowledgments}

This study was supported by the National Natural Science Foundation (41072082), National Basic Research Program of China (No. 2005CB422106), national key subject constructional item of mineralogy, petrology and mineral deposit (SZD0407) and backup candidate fund of academic and technical senior scholar in Sichuan Province. The authors acknowledge constructive comments of anonymous reviewers.

\section{References}

Ai X M, Zeng Q L and Wang W. Conditions for hydrocarbon preservation in the upper assemblage of Shizhu area. Journal of Oil and Gas Technology. 2006. 28(1):19-22 (in Chinese )

Banner J L and Kaufman J. The isotopic record of ocean chemistry and diagenesis preserved in Nonluminescent Brachiopods from Mississippian carbonate rocks, Illinois and Missouri. Geological Society of America Bulletin. 1994. 106: 1074-1082

Chao G X and Luo X P. A preliminary analysis on hydrocarbon preservation condition of marine beds in middle Yangzi region. Oil \& Gas Geology. 1996. 17(1): 44-47 (in Chinese )

Chen A D, Yang Z W, Huang J M, et al. The standard used for oil-gas protection condition evaluation of the lower Yangtze marine Mesozoic and Paleozoic, southern China. Oil \& Gas. 2004. 17(4) : 10-13 (in Chinese)

Chen Z M, Wu Y Y, Lv Y H, et al. Study on Preservation and Destruction of Trapped Hydrocarbons. Beijing: Petroleum Industry Press. 2003. 1-95 (in Chinese)

Denison R E, Koepick R B, Burke H, et a1. Construction of the Cambrian and Ordovician seawater ${ }^{87} \mathrm{Sr} /{ }^{86} \mathrm{Sr}$ curve. Chem. Geol. 1998. 152: 325-340

Faure G. Principles of Isotope Geology. New York: John Wiley Sons. 1977. 97-146.

Fu X Y, Wang J Y and Zhang H R. Preservation mechanisms and conditions for natural gas in southern China. Marine Origin Petroleum Geology. 2002. 7(2): 43-47 (in Chinese )

Guo T L, Lou Z H and Ma Y S. Several problems on oil and gas preservation and their commercial prospecting in marine sequences of south China. Petroleum Geology \& Experiment. 2003. 25(1): 3-9 (in Chinese)

He D F, Ma Y S and Yang M H. Concept and appraisal principles of hydrocarbon preservation unit. Oil and Gas Geology. 2004. 25(1): 1-8 (in Chinese)

Heydari E. Porosity loss, fluid flow and mass transfer in limestone reservoirs: application to the upper Jurassic Smackover formation, Mississippi. AAPG Bulletin. 2000. 84(1): 100-118

Hu X F, Wang S H, Sheng X C, et al. Hydrochemical characteristics and hydrocarbon preservation of marine strata in the central Yangtze. Journal of Oil and Gas Technology. 2007.29 (2): 32-37 (in Chinese)

Huang S J, Shi H, Zhang M, et al. Application of strontium isotope stratigraphy to dating Ordovician marine sediments. Acta Sedimentologica Sinica. 2004. 22(1): 1-5 (in Chinese)
Huang S J, Wu S J, Sun Z L, et al. Seawater strontium isotopes and paleo-oceanic events over the past 260 Ma. Earth Science Frontiers. 2005. 12(2): 133-141 (in Chinese)

Jin Z J. Petroliferous features of marine carbonate strata and hydrocarbon resource prospects in China. Frontier Science. 2010. 4(13): 11-23 (in Chinese)

Jin Z J, Long S X, Zhou Y, et al. A study on the distribution of salinedeposit in south China. Oil and Gas Geology. 2006. 27(5): 571-583 (in Chinese)

Lou Z H, Ma Y S, Guo T L, et al. Evaluation of oil and gas preservation conditions in marine formation in south China. Natural Gas Industry. 2006. 26(8): 8-12 (in Chinese)

Ma L, Chen H J, Gan K W, et al. Geotectonics and petroleum geology of marine sedimentary rocks in southern China. Beijing: Geological Publishing House. 2004. 328-364 (In Chinese)

Ma Y S, Lou Z H, Guo T L, et al. An exploration on a technological system of petroleum preservation evaluation for marine strata in south China. Acta Geological Sinica. 2006. 80(3): 406-417 (in Chinese)

McArthur J M. Recent-trends in strontium isotope stratigraphy. Terra Nova. 1994. 6: 331-358

Pan G E and Yang C Z. Oil-gas preservation condition of marine carbonate rocks in south China. Oil and Geology. 1992. 13(3): 332343 (in Chinese)

Reinhardt E G, Blenkinsop J and Patterson R T. Assessment of a Sr isotope $\left({ }^{87} \mathrm{Sr} /{ }^{86} \mathrm{Sr}\right)$ vital effect in marine taxa from Lee Stocking Island, Bahamas. Geo. Marine Letters. 1998. 18(3): 241-246

Shi H, Huang S J, Shen L C, et al. Stratigraphical significance of the strontium isotopic curve of the upper Paleozoic of Sichuan and Guizhou. Journal of Stratigraphy. 2002. 26(2): 106-110 (in Chinese)

Surdam R C. Seals, traps, and the petroleum system. AAPG Memoir. 1997. 67:31-48, 57-84

Wang G Z and Liu S G. Paleo-fluid geochemical evaluation of hydrocarbon preservation in marine carbonate rock areas: taking lower association in central Sichuan basin as an example. Journal of Chengdu University of Technology (Science and Technology Edition). 2009. 36(6): 631-644 (in Chinese)

Wang G Z, Liu S G, Su W C, et al. Water soluble gas in deep Carbonate reservoir, Sichuan Basin, southwest China. Journal of China University of Geosciences. 2008. 19(6): 636-644

Wo Y J and Wang X W. Geologic configuration types of the middleupper Yangtze region and their significance for hydrocarbon preservation in marine strata. Oil and Gas Geology. 2009. 30(2): 177187 (in Chinese)

Yang F Z, Ma Y S and Fu X Y. A geological characteristics and exploration evaluation of natural gas accumulation formation of marine strata in south China. Southern China Oil and Gas. 2002. 15(3-4): 2-15 (in Chinese)

Zhang Z C. ${ }^{87} \mathrm{Sr} /{ }^{86} \mathrm{Sr}$ data for some middle-late Proterozoic to early Cambrian carbonate rocks in China. Geological Review. 1995. 41(4): 349-354 (in Chinese)

Zheng Y F. Theoretical modeling of stable isotope systems and its applications to geochemistry of hydrothermal ore deposits. Mineral Deposits. 2001. 20(1): 57-70 (in Chinese)

(Edited by Yang Lei) 